\title{
The Usage of the Flipped Class Model when Teaching International Students Theoretical Disciplines at the Philological Faculty
}

\author{
Yulia Naumenko $^{1 *}$, Lilia Vokhmina ${ }^{1} \&$ Ekaterina Budnik $^{2}$ \\ ${ }^{I}$ Pushkin State Russian Language Institute \\ ${ }^{2}$ Moscow State Linguistic University
}

\begin{abstract}
One of the teaching models which stimulates and motivates students' studying activities is the flipped class, which "turns over" the traditional order of the material (a lecture - homework) vice versa. The purpose of this work is to present the effectiveness of the usage of the flipped class model when teaching international students' theoretical disciplines in Russian at the philological faculty at Pushkin State Russian Language Institute. The traditional way of giving the material of theoretical disciplines to the international students didn't show the high results: the students couldn't master the material in full, didn't understand texts of the lectures due to an insufficiently formed lexical stock and couldn't do practical tasks and tests. The students met significant difficulties during the performance of the certification work. It became clear that the special preparative work must be done with the students before they begin to listen to lectures. So, the teaching and academic staff of the department (Department of Methodology of Teaching Russian as a Foreign Language) at the philological faculty decided to change the traditional way of giving theoretical lecture material in Russian for the international students into the flipped class teaching model. In 2019-2020 academic year the international students got the new formatted material under study within the theoretical discipline "Aspect study of the Russian Language in an international audience". LMS Canvas was used as an educational platform, where the students got different tasks with video lectures, articles, questions, practical exercises. At the end of the term the students completed the certification work. And the high points which the students got for the work indicated the correctness of the chosen teaching model.
\end{abstract}

Keywords: teaching international students, traditional format of teaching, flipped class teaching model, Russian and international audience

\section{Introduction}

Nowadays the international education system has been expanding its boundaries and a lot of students from other countries come to Russia to get their professional education. Thus, one of the priority areas of activity of many Russian universities is to create such educational system for international students which can provide them with the professional education at the proper level. The first problem is that international students must study in a language that is not their native language. But the requirements for the amount of knowledge which is got by Russian and international students in the learning process are the same. In this regard, the question arises: how to teach international students, so that in the end they can get knowledge of the required volume and complete certification work with high points. A review of studying at the philological faculty is a good example of such a difficult task.

Recently the number of international students at the philological faculty in Russia has been increasing. It means that more and more international students are eager to get the Russian language skills for their future activities in their countries. Studying at the philological faculty (in addition to consolidating the skills of proficiency in the Russian language in the everyday sphere) allows students to obtain the necessary linguistic and methodological knowledge, to form the skills and abilities to teach the Russian Language to a international audience. The specificity of teaching philological and methodological disciplines to international students means first of all the professional orientation of education, then the careful choice of methods of working with an 
international audience, the selection, organization and methods of the presentation of the educational material, i.e. the methods of its presentation should be adapted in such a way to the needs and requirements of international students, so that students can learn it in the right volume and at the proper level. It is mentioned above already that it is a difficult task as international students must study in the Russian Language, not in their native languages. And the existing textbooks and teaching aids on philological and methodological disciplines are focused mostly on Russian students. And the teaching process usually has the so-called traditional format: first students attend and listen to lectures given by professors, then students discuss the key-questions during the practical classes (seminars). And such traditional format is used in the groups of Russian and international students. It should be added that these groups of Russian and international students can be separated in some universities and can be mixed in others. For example, in Pushkin State Russian Language Institute (Russia, Moscow) Russian and international students study separately and it gave a good opportunity to make a research in 2019-2020 academic year when it turned out in 2018-2019 academic year that the traditional way of presenting the educational material of such a theoretical discipline as "Aspect study of the Russian Language in an international audience" didn't bring the desired result: traditionally the same theoretical material with the subsequent analysis of difficult questions and the implementation of additional tasks at practical seminars was given separately in the group of Russian students and international ones. International students couldn't master the material under study in full: they didn't understand texts of given lectures due to an insufficiently formed lexical stock. As a result, they couldn't complete practical tasks and tests. Moreover, at the end of the term (1st term) international students experienced significant difficulties while performing the certification work and could not get high points. Thus, the teaching and academic staff of the department (Department of Methodology of Teaching Russian as a Foreign Language) at the philological faculty had to find a solution to the problem of presenting theoretical lecture material to international students, to change the method and way of its presentation. And then the flipped class teaching model was chosen for an audience of international students. The choice of such a teaching model as a flipped class was not random. The description of this model is beyond the boundaries of this paper as the model is well-known and well-presented in many papers and researches. The aim of the current paper is to show how this model can be used while giving the material of theoretical disciplines to international students. The paper presents the authors' material which is based on the analysis of theoretical, methodological literature with covering the so-called traditional and informational (digital) pedagogical technologies in teaching Russian as a foreign language. And this material was prepared when teaching international students such a theoretical discipline as "Aspect study of the Russian Language in an international audience".

\section{Methodology}

As it is known, the essence of the flipped class teaching model is to change the traditional order of the studied material: the "turned over" material. In the traditional teaching format students listen to some lecture material, then complete their homework. Within the flipped class model students should first view some videos of lectures, complete tasks to them (for example, reading additional literature, preparing answers to questions, completing test tasks). And then in the classroom the most difficult theoretical questions are discussed (it helps a teacher to check whether students understood the material or not), tasks of a "creative" nature are performed to revise the studied material: they are discussions, debates, joint or individual projects. The teacher can also offer the implementation of practical tasks (exercises).

For working with international students this teaching model seems to be the most successful. Such an order of the material under study, when students have the opportunity to independently prepare for its subsequent active joint discussion (in a broad sense) at the lesson, should first help to reduce the number of lexical (sometimes grammatical) difficulties, as well as difficulties associated with the perception of the sounding text., i.e. listening, and then, possibly, eliminating them. The possible difficulties can vary. It depends on the nationality of students and their native languages. Students from Southeast Asia are more likely to have listening difficulties than students from, for example, the Middle East or Eastern Europe. This means that when preparing 
self-study material, the teacher must prepare the block of tasks that should help students of this particular nationality to cope with specific difficulties.

Another advantage of this teaching model for working with international students is that students can refer to the material as many times as they need. During the traditional listening to lectures international students don't always have the opportunity to ask the teacher to repeat the material (or even to explain the meaning of the words). Also, students should have time to write down the teacher's words. And within the flipped class model students can fully control the process: they can watch the video lecture as many times as they need; they can stop the recording at the right place and check the meaning of words. This type of work is of great importance for international students, as it is mentioned above, students face some difficulties in studying theoretical disciplines.

It is worth noting that the flipped class model has a student in the centre of the educational process: he should be actively involved in this process, which contributes to the development and improvement of individual responsibility, social skills, as well as the development of memory, attention and critical thinking. Students have the opportunity to use different communication strategies. At the same time the educational autonomy of students is manifested (they decide when, where, at what pace and for how long they will study the given material), educational and cognitive activity of students, skills and abilities to work in a group are improved (Avramenko and Abdullaeva, 2016).

The teacher plays the role of a "mentor" who organizes, directs and controls the educational process, corrects mistakes, helps in understanding difficult material. The teacher acts as a trainer, a consultant, who encourages students to do independent research and work together.

The next two important questions are: 1) how students can receive this educational material and perform the given tasks and tests; 2) how a teacher can do the control.

There are some Learning Management Systems (LMS) that can help in solving these issues. These systems are a tool with which the following operations can be done: administration, placement and structuring of educational material, providing access to materials, organizing the interaction of participants, controlling the educational process, generating a report on the results of teaching. These LMS are Moodle, Canvas, Google Classroom, iSpring, Mirapolis, Teachbase, Eliademy and others. As Pushkin State Russian Language Institute uses LMS Canvas, the authors decided to use this particular system. And the teachers had to prepare the material with the help of this LMS. It means the following steps:

- to explore the capabilities of LMS Canvas;

- to think over the organization of the material in the course;

- to fill the course with the content;

- to plan the grading system in the course;

- to set up a schedule for passing the course through the definition of deadlines for the tasks;

- to draw up instructions for students on how to work in the system.

As there is no strict system for presenting material within the flipped class model, the following decision was taken on the content of the course:

Stage I: self-study material for international students. This stage of work in this sequence of studying elements is absent in the group of Russian students. 
1) the small video lectures up to 15 minutes long (there may be several such video lectures within one theme). Each video lecture has an addition in the form of the text of the lecture in printed form (this is especially important for international students as they compare the listened text and the printed one when they have some difficulties in perception) and the form of a Power Point presentation;

2) the list of questions about the text of the lecture. And these questions should be "detailed": there can be several questions per a paragraph of the text. This makes students be attentive and study the given material carefully. And besides this the teacher can check how well students understand the material;

3) the test tasks of a closed type;

4) the list of both basic and additional literature, which can help students in case of any questions.

Figure 1 shows the gotten structure of the 3rd theme "The Description of the Vocalic System in the Aspect of the Russian Language as a Foreign One" within the studied discipline. It contains the text of the lecture, a Power Point presentation, the list of questions, the list of literature, two types of assessment tasks and video lectures.

\begin{tabular}{|c|c|c|c|c|}
\hline \multicolumn{2}{|c|}{ :: - Раздел 3. Описание системы вокализма в аспекте РКИ } & 0 & + & \$ \\
\hline :: & Текст лекции 3 & & 0 & $\$$ \\
\hline : & Презентация лекции 3 & & 0 & \$ \\
\hline :: & Контрольные вопросы-3 & & $\infty$ & $\$$ \\
\hline$::$ & Литература раздела-3 & & 0 & $\$$ \\
\hline :̈ & $\begin{array}{l}\text { Задание к лекции } 3 \\
3 \text { балл (-a, -ов) }\end{array}$ & & 0 & $\$$ \\
\hline :̈: & $\begin{array}{l}\text { Задание к лекции } 3 \\
3 \text { балл (-а, -ов) }\end{array}$ & & 0 & \$ \\
\hline :: & Видеоматериалы & & 0 & $\phi$ \\
\hline
\end{tabular}

Figure 1. Theme 3. The Description of the Vocalic System in the Aspect of the Russian Language as a Foreign One

Stage II: listening to the teacher's lecture in the classroom. International students should listen to the text, make the necessary notes in their notebooks, answer the teacher's questions, give their own examples, participate in the discussion of any problematic subtopics.

This stage of work is the same for both a group of Russian students and a group of international ones. At the end of the lecture students from both groups receive their homework. First Russian students receive that task which international students should have already completed before the lecture: the printed text of the lecture, the presentation that the teacher used during the lecture, a list of detailed questions, a list of basic and additional literature. And then students of both groups receive the same tasks. The choice of the tasks depends on the theme of the studied material. The tasks can be the following: writing a summary of the read work (for example, 
articles by leading researchers in the field), performing practical tasks (for example, finding answers to the given questions in the researcher's work), drawing up a table, diagrams based on the content of the studied article, monograph, viewing additional video materials, studying additional electronic resources containing material on the theme under study, etc.

Stage III: checking the completed tasks at the practical classes (seminars). This type of work is the same for Russian and international students. The types of work in the seminar depend on the tasks which students received as homework. This can be, for example, brainstorming a question, presenting a report based on a completed group or individual task (project), answering detailed questions for a lecture test, performing practical exercises, tests, etc.

The organization of the material in the course for Russian and international students requires one more comment. Following the curriculum, 72 academic hours are given for each group for studying the material of the course "Aspect study of the Russian language in an international audience" within the first term: 6 academic hours for lectures, 10 academic hours for seminars, 54 academic hours for self-study work and 2 hours for certification work. The lecture hours and seminar hours in both groups are held in parallel. The hours given for self-study work are distributed in different ways. In the Russian group students start completing tasks as part self-study work after listening to the lecture given by the professor in the classroom. In the international group students complete part of the tasks (the so-called preparatory stage) before listening to the lecture (reading the text of the lecture, studying the presentation material, preparing answers to detailed questions, passing tests), some of the tasks ("creative" ones) should be done after the listening to the lecture. As a result, the volume of tasks for self-study work in both groups is the same. But Russian and international students complete these tasks at different time. In the same "mismatched" way students should receive points for their work.

\section{Results}

First, we should compare the conditions of studying of the international students in 2018-2019 and 2019-2020 academic years. The Russian groups of students of both academic years studied in the same way: traditional format, so there is no sense to describe their conditions of studying. All the students were first-year Master students.

In 2018-2019 academic year there were two groups of international students: 17 and 24 from China, Vietnam, Turkey. And they studied the material of the theoretical discipline "Aspect study of the Russian Language in an international audience" in the traditional format: first lectures, then seminars. During the lectures the students met lexical (sometimes grammatical) and listening difficulties. The students from China and Vietnam met the most difficulties. Though they had a rather large linguistic and methodological stock of words, they couldn't "hear" the lecture and so couldn't make notes. As a result they asked the professor to give them the text of the lecture to read or they asked for permission to record the lecture to listen to it at home again and to write down the most important moments of the lecture in their notebooks. Such teaching and studying seemed to be not effective: the professor gave good lectures, but the international students didn't understand them in a full way and had to deeply revise the material at home themselves. And at the end of the term (1st term) the international students experienced significant difficulties while performing the certification work and could not get high points.

In 2019-2020 academic year there was a group of 21 international students from China, Vietnam, Thailand, Turkey, Iran, Serbia, Hungary. The teaching material for these students was prepared by the teaching and academic staff at the department at the philological faculty (Department of Methodology of Teaching Russian as a Foreign Language) in the new format within the discipline "Aspect study of the Russian language in an international audience": flipped class model. The description of the structure and the presentation of the content of the course is given above. 
The purpose of such different models of teaching during these two academic years is to check whether the international students teaching within the flipped class model allows them to study the material of the given discipline in a full way and with high points.

The result at the end of the 1st term of 2019-2020 academic year, when the first (phonetic) part of the discipline was over, was good. During the term the international students could master the material under study in full: they understood the texts of the given lectures, could complete practical tasks and tests, could answer the given questions at the seminars and performed the attestation test at the end of the term with rather high points. They were much higher than those ones which the international students of 2018-2019 academic year got. The indicators generally improved by 10 points on a 100-point system, i.e. the international students of 2019-2020 academic year received from 80 to 100 points, which corresponds to the marks of "good" and "excellent" on a 5-point system.

In 2020-2021 academic year the teaching the international students within the flipped class model is going on. Now there is a group of 28 international students from China, Vietnam, Japan, Romania, Serbia. And it is being done in the new conditions due to the events related to the spread of coronavirus in the world: the ZOOM program is used for giving lectures and seminars. Figure 2 shows a work episode in the current conditions.

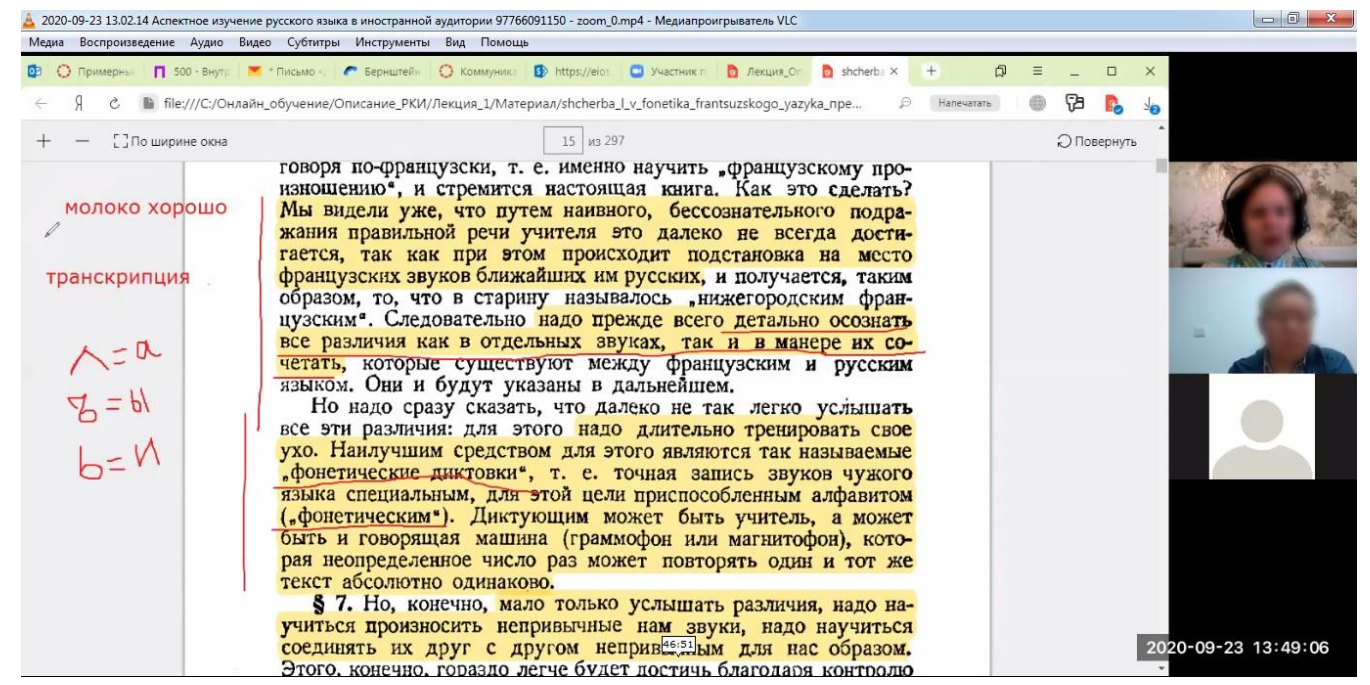

Figure 2. The online seminar

There is a positive trend: the international students gain high points for the tasks they perform.

\section{Conclusions}

The presented material shows the effectiveness of using the flipped class model in teaching theoretical disciplines to international students, confirms the correctness of the choice of the teaching model made by the teaching and academic staff at Pushkin State Russian Language Institute. It is planned to use the flipped class model in teaching other theoretical disciplines to international students at the institute.

\section{References}

Avramenko, A. \& Abdullayeva, P. (2016). Didactic potential of LMS for the formation of student's sociocultural competence. Collection of scientific and educational works. Issue 13. KDU, University book Moscow, 113-121. 
Fedotova, O. \& Nikolaeva, E. (2017). Alternative educational technology Flipped learning as an implementation of the idea of a radical revision of the organizational foundations of the learning process. Mir nauki. Vol. 5, No. $1 ., 52-58$.

Lebedeva, M. (2016). Mixed Learning the Russian Language; Limitations, Implementation Models and Prospects. Pedagogical Journal of Bashkortostan. No. 5 (66), 59-65.

Sharma, P. \& Barrett, B. (2007). Blended learning: Using technology in and beyond the language classroom. Oxford: Macmillan, 160 p.

Zhernosek, A. (2017) Ways to prepare and conduct lectures when using the technology of training " Flipped class». Collection of materials of the Republican scientific and practical conference with international participation. Vitebsk: publishing house of Vitebsk state medical University, 33-35. 